\title{
Citizenship in a Post-Colonial Context: Comparing Portugal and the Netherlands
}

Patrícia Jerónimo

Maarten Peter Vink

Patrícia Jerónimo, Assistant Professor

School of Law University of Minho, Braga, Portugal ppmj@direito.uminho.pt

Maarten Peter Vink, Associate Professor

Department of Political Science

Maastricht University, Maastricht, The Netherlands

m.vink@maastrichtuniversity.nl 
ABSTRACT:

This paper analyses citizenship and migration regimes in a postcolonial context and presents a focused comparison of the experiences in Portugal and the Netherlands. While colonial regimes in both cases were largely exclusionary, and only towards the end of the regimes hesitantly extended citizenship to the native population, the postcolonial experiences display significant differences. While Portugal is more nostalgic about the colonial affair cherishing the idea of cultural ties within a Lusophone community, the change was more abrupt in the Netherlands, after an initial transition period. The comparison in this paper highlights how these two countries dealt with the loss of empire.

KEYWORDS:

Post-colonialism; citizenship; migration; Portugal; Netherlands

\section{Citizenship in a postcolonial context}

Post-colonialism is a term with multiple meanings and political associations. First of all we define "postcolonial" to mean the context generated by the independence of territories that were under European rule from the fifteenth century up until the second half of the twentieth century. While this definition is seemingly straightforward, understood in a chronological sense to demarcate the transition from colonialism to self-determination among formerly colonised nations, it is also a term that has generated significant controversy. To some, suggesting that imperial dominance is a thing of the past, overlooks the continuing 'neo-colonial' imbalances in political and economic relations between the West and developing countries (McClintock, 1992: 85-91; Santos, 2002: 16). Others, however, argue that postcolonialism does not need to fall in the neo-colonial trap of overlooking continuing asymmetries, but can be a useful perspective on "how the past informs the present" (Darian-Smith, 1996: 292). "Postcolonial time is that in which colonial experience appears, simultaneously, to be consigned to the past and, precisely due to the modalities with which its 'overcoming' comes about, to be installed at the centre of contemporary social experience - with the entire burden of domination, but also the capacity for insubordination, that distinguishes this experience" (Mezzadra and Rahola, 2006).

In this paper, we are interested in analysing the notion of citizenship in a postcolonial context, and in particular the question of how the colonial experience of the past influences citizenship and migration regimes in former colonial powers. How do these different experiences affect today's citizenship and migration regimes in these two opposite cases? How did they deal with the loss of empire after decolonialisation? We focus on two cases, Portugal and Netherlands, both colonial powers for centuries long, often in competition for maritime dominance, but with fundamentally different colonial experiences. The paper will look at how decolonization impacted the way in which the two former colonial empires under scrutiny regulated the access to citizenship in the immediate aftermath of decolonisation and at the relevance of postcolonial ties in the access to citizenship at a later stage. It will also look at the way in which these countries have dealt with postcolonial immigration, understood as immigration originating from their former colonies, in view of the fact that, like with other former colonial powers, immigration is to a large extent an inheritance of their colonial past (Van Amersfoort and Van Niekerk, 2006: 323). That is particularly so in Portugal, which only recently became a country of immigration and where the overwhelming majority of the 
immigrant population is made up of foreigners originating from Brazil and Portuguese speaking countries in Africa (Machado, 1994: 112; Carvalhais, 2010: 4).

In colonial times it was common practice for colonising regimes to differentiate between European born citizens, who were full citizens, subject to metropolitan law, and the indigenous populations, with no political rights and administered by the customary laws of each territory. For most of the time under colonial rule there were no principled differences between the two cases under scrutiny in this study, Portugal and the Netherlands, with regard to the citizenship regime versus the resident population in the colonies. On the one hand, there was a functional need to provide a legal status to the indigenous colonial population, as a governing imperative, but on the other hand, government aimed at doing so "without applying the principles of constitutional government prevailing in Europe" (Mezzadra, 2005: 34).

Similarly, in the final years of their empires, both the Dutch and the Portuguese extended full citizenship to all their colonial subjects, albeit in the case of the Netherlands only after the independence of its largest colony, Indonesia. Following decolonisation, the Netherlands and Portugal cut their ties with the large majority of their previous overseas citizens, depriving them of Dutch and Portuguese citizenship. However, while the Netherlands, after an initial transitional period in which access to the Dutch territory and citizenship was made easier for persons coming from its former colonies, moved on to treat them as mere foreigners, Portugal kept treating the foreigners coming from Portuguese speaking countries as special, granting them easier access to Portuguese territory and citizenship, as well as a quasi-citizenship status.

Unlike the Netherlands, which for a long time viewed access to citizenship as a tool for integration, Portugal did not justify the privileged regime granted to Lusophone immigrants as a way to foster their integration. In Portugal it was always assumed that immigrants coming from former colonies would have no difficulties in integrating into Portuguese society, given that they would know the language, were familiar with the mores, etcetera. This preferential status has consistently been justified on the basis of a necessary recognition of the special cultural, historical and linguistic ties that bind Portugal to its former colonies, a principle that is enshrined in the Portuguese Constitution as a governing principle of Portuguese international relations (Ramos, 1990: 589-591; Miranda, 1998: 153158). This observation points at the main difference between the ways in which 
the two countries dealt with loss of empire. While Portugal was more nostalgic about the colonial affair, cherishing the idea of cultural ties within a Lusophone community, the change was more abrupt in the Netherlands, after an initial transition period.

In what follows we first discuss the Portuguese and Dutch postcolonial experience separately, and subsequently follow with a comparison and broader discussion of the two cases.

\section{The Portuguese experience}

Portugal was the last of the European empires to surrender its colonies and it was the one which suffered most from the loss of empire. The independence of the overseas territories was not a mere reduction of the space where Portuguese sovereignty could be exercised. The idea of a pluri-continental nation, built on the Lusotropicalist perception of Portugal's gift for intercultural dialogue, was, and to some extent still is, a powerful element of Portuguese psyche. Lusotropicalist theory became anathema after 1974, for its use as a political tool under the Salazar regime. Yet, its main idea, that Portugal was a better, more humane, coloniser, still pervades much of the Portuguese sense of self (Castelo, 1999). As Ramos (1976: 136) points out, the origin and raison d'être of Portuguese culture are strongly connected with Portugal's geographic position and maritime expansion. One cannot understand Portugal's quid specificum without the Discoveries and the maritime expansion of the fifteenth and sixteenth centuries, a golden age celebrated to this day. Hence it is not surprising that Portugal's postcolonial reconstruction revolves around the maintenance of special ties with peoples from former colonies with which Portugal shares cultural traits such as language, religion and mores (Ramos, 1976: 137). The years after Portugal's retreat from Africa were characterised by a complex of unstable relationships, changing objectives and uncertain rapprochements with the former territories which have been as much psychological as political, but the idea of a special relationship with the Lusophone world remained potent across the spectrum of Portuguese politics (MacQueen, 2003: 182). The fact that all former colonies kept Portuguese as official language, and notwithstanding the variety of local languages and dialects, allowed Portugal to reposition itself as the centre of a linguistic community. Portugal could, therefore, continue its "Atlantic vocation" and show the world that it was "not a small country". 
Under colonial rule the Portuguese empire distinguished between natives (indigenas) and non-natives (não indígenas). This was formalized in the Indigenous Statute (Estatuto do Indigenato), adopted in 1926, which was subsequently incorporated in the Colonial Act (Acto Colonial) of 1930. The Act was a legal instrument designed to be the "Constitution of the Empire" which reasserted the historical mission of the Portuguese nation to possess and colonise the overseas territories and civilise the indigenous population resident in those territories. The Act recognised the right of the indigenous people to be protected and to enjoy freedom of expression, work and property. However, it also prescribed that the State had the right to force them into labour on public works (Horta and White, 2009: 38). Under the Statute and the Act, the indigenous peoples from the territories of Guinea, Angola and Mozambique had specific legal statuses - the personal status - designed to accommodate the local customary norms and practices, provided that they were not contrary to morals, humanity requirements and the free exercise of Portuguese sovereignty (Ramos, 1992: 44-46).

Under the Indigenous Statute, the non-natives, European born Portuguese and white-skinned foreigners, were full Portuguese citizens subjected to metropolitan laws, whereas the natives were administered by the customary laws of each territory. Access to benefits and rights was contingent on the natives' ability to conform to or mimic the colonial power (Kapur, 2007: 567). Only a small minority of Africans and Asians ever achieved the right to be treated on the same legal basis as whites, a status known in the Portuguese colonies as assimilado. The small number of assimilados in the Portuguese colonies can be explained by two main reasons: the fact that the status of assimilado did not amount to full citizenship, nor prevented social and economic discrimination; and the fact that the assimilados had to pay taxes at the rates levied on metropolitan citizens, which refrained thousands of "civilised" Africans from applying for the status (Horta and White, 2009: 39).

This assimilationist policy created an official categorisation of the population into three major groups, consisting of Portuguese citizens, assimilados, and the remaining indigenous populations (Horta and White, 2009: 39). Only in the very last years of empire did Portugal offer full citizenship to all its colonial subjects, and that was due to the strategic interest in portraying Portugal as a "single and indivisible" pluri-continental and multiracial State with overseas provinces, rather than colonies. 
Faced with international criticism and pressure, the Salazar regime amended the Constitution, in 1951, to replace the references to "colonies" and "colonial empire" by references to the "overseas provinces" (provincias ultramarinas) and the "Portuguese Overseas" (Ultramar Português). The 1951 constitutional reform also defined the status of the indigenous as transitory, following which a new law on the Portuguese Overseas was passed in 1953 and a new Indigenous Statute for the Provinces of Guinea, Angola and Mozambique was promulgated in 1954. In 1961, new administrative reforms were introduced whereby the Indigenous Statute for the Provinces of Guinea, Angola and Mozambique and the status of assimilado were abolished. From then on, for the final years of Portuguese colonialism, all the residents of the overseas provinces became, in theory, full citizens of Portugal (Horta and White 2009: 39-40).

At the time of the independence of the Portuguese overseas provinces, in 1975, many African Portuguese citizens had fled their countries due to the war and were living as repatriates in Portugal. Fearing an invasion of Portuguese citizens of African origin, with a legitimate right of abode, the Portuguese government decreed that all persons born or resident in an overseas territory turned independent would lose Portuguese citizenship (Decree-Law 308-A/75). Portuguese citizenship could only be retained in exceptional circumstances. This rule applied to persons from all former colonies, except those from East-Timor, as Portugal never acknowledged the unilateral declaration of independence, made by the Revolutionary Front for an Independent East Timor on 28 November 1975, nor accepted as legitimate the Indonesian occupation of the territory in December of that same year. After much criticism (e.g. Ramos, 1976: 340-341), the Decree Law 308-A/75 was repealed in 1988, albeit without retroactive effect.

In the meantime, in 1981, a new Nationality Law was adopted (Law 37/81), replacing the previous Law from 1959. The 1981 Nationality Law reflected the new concept of polity and citizenship that came with the end of the empire. The political regime had by then become more stable, the Constitution was highly protective of fundamental rights and the State was already bound by several international human rights treaties. The retreat of the State to its European niche following decolonisation and the high numbers of Portuguese emigrants forced a departure from the primacy of ius soli and an overall re-conceptualisation of the nature of nationality ties (Ramos, 1992: 99-111). That explains the relevance of individual will in the definition of the nationality relation, in line with article 15 of the Universal Declaration on Human Rights. That also explains the new balance struck 
between ius soli and ius sanguinis, signifying the value attributed to the human aspect of State building (Ramos, 1999: 403).

Under Law 37/81, Portuguese by origin were the children of a Portuguese father or mother born in Portuguese territory or in territories under Portuguese administration, referring to Macau and Timor-Leste. The reference to territories under Portuguese administration was removed from the Law in 2006 after the situation in those territories had changed in 1999 with the integration of Macau in China and with the establishment of a Transitional United Nations Administration in Timor-Leste, following the end of the Indonesian occupation. Portuguese by origin were also the children born abroad if the Portuguese parent was there serving the Portuguese State, as well as the children born abroad to a Portuguese parent if they declared their will to be Portuguese or if they had their birth registered at the Portuguese civil registry.

The primacy of ius sanguinis is not without limits, however, given that the children of Portuguese parents born abroad are not Portuguese ope legis, but only after a declaration of will to that effect (Miranda, 1998: 114). However, it is significant that successive generations of Portuguese descendants may, until infinity (Canas, 2006: 864-865), avail themselves of the possibility of being considered Portuguese by origin, simply by registering their births at the civil registration or by declaring their will to be Portuguese, even if they have no real ties to the national community.

As for the ius soli, the birth in Portuguese territory was only a condition of attribution of citizenship by origin when the person had no other citizenship and when the person's foreign parents had resided in Portugal for at least six years and were not serving their respective State, in which case, the person still had to declare his or her will to be Portuguese - requirements justified as a means to avoid the attribution of citizenship by origin in cases where there was no significant integration in the local community (Ramos, 1999: 404). Naturalisation was a purely discretionary act of the Government (Miranda, 1998: 116-117). The Government could grant naturalisation, upon request, to foreigners who satisfied five cumulative requirements: to be of age or emancipated under Portuguese Law; to have resided in Portuguese territory for at least six years; to have sufficient knowledge of the Portuguese language; to have good moral and civic standing; and to have the capacity to look after oneself and guarantee his or her subsistence. Exempted of the residence and language requirements were, among others, persons who had 
had Portuguese citizenship, including those who lost Portuguese citizenship as a consequence of Decree-Law 308-A/75.

Law 37/81 is still the Law in force, although its provisions have been amended in the context of four different reforms (see also Piçarra and Gil 2010; Carvalhais 2010 for an overview of developments in Portuguese nationality law). The two major reforms took place in 1994 and in 2006. The 1994 reform introduced a clear distinction between Lusophone and non-Lusophone foreigners, granting the former a more favourable regime in the name of the special ties between Portugal and the Portuguese speaking countries. This first reform had a clearly restrictive purpose, which can be explained as a response to the immigration pressures that were beginning to be felt in Portugal. It: a) gave the Government a wide margin of intervention; b) reduced even further the weight of ius soli, by raising to 10 years the residence requirement for foreign parents of non-Lusophone origin and by adding the requirement that the residence be lawful; c) made naturalisation more difficult, by raising to 10 years the minimum residence requirement for all nonLusophone applicants and by demanding that the residence be lawful; and, d) made it easier for the Government to oppose the acquisition, by transferring to the applicant the burden of proof of an effective connection to the national community.

The 2006 reform in general had a substantive inclusive effect. It strengthened the ius soli criterion, by attributing Portuguese citizenship by origin to children born on Portuguese territory to foreign parents if at least one of the parents was also born in Portugal and resides there, irrespective of title, at the time of birth (double ius soli). The new Law also reduced to five years the residence requirement for attributing Portuguese citizenship by origin to the children born in Portuguese territory to foreign parents (not serving their respective State) who declare that they want to be Portuguese.

The introduction of the double ius soli was aimed at solving the integration problems faced by "third generation immigrants", and amounted in practice to an extraordinary regularization process of many of the illegal immigrants resident in Portugal (Alexandrino 2008). There were strong reasons to do so, as Canas (2006: 853) observes, because the regime instituted in 1981 (and made even stricter in 1994) was a source of de facto statelessness. After all, 'third generation immigrants' in fact are not immigrants at all, but children born in Portugal to persons born themselves in Portugal. Previously these persons did not acquire Portuguese nationality de jure, which denied the citizenship status to those whose sole and effective ties are with Portugal. 
The residence requirement for attribution of Portuguese citizenship by birth was set at five years, while the residence requirement for naturalisation was set at six years for all foreigners. Also regarding naturalisation, the 2006 reform reduced considerably the list of requirements and, more importantly, conceives naturalisation as an individual right and the naturalisation process as a bounded exercise of power (poder vinculado). The current requirements are that the foreigners be of age or emancipated under Portuguese Law; that they have resided lawfully in Portuguese territory for a minimum of six years; that they have sufficient knowledge of the Portuguese language and that they have not been convicted of a crime punishable under Portuguese Law with imprisonment up to a maximum equal to three years or more. It is no longer required that foreigners have good moral and civic standing - although committing certain types of crimes may be reason to reject a naturalisation request - nor that they have the capacity to look after themselves and guarantee their subsistence. The requirement to prove effective ties to the national community was also abolished in 2006. This was of particular importance in view of the abundant number of cases where naturalisation was denied in the past to persons fulfilling residence and language requirements, on the grounds of a lack of effective ties with the community (Canas, 2006: 867). Even though the requirement of effective ties to the Portuguese community is still implied by the residence and language requirements, under the revised Nationality Law the abolishment of the requirement of effective ties substantially decreases the administrative discretion in the naturalisation procedure.

In order to bring the Portuguese law in line with the anti-discrimination provisions of the European Convention on Nationality, the 2006 reform also put an end to the positive discrimination regime in favour of Lusophone foreigners. Some argue, however, that the privileged status granted to Lusophone foreigners still persists in the form of language requirements for naturalisation (Marques, 2007: 427-428). Be that as it may, the fact is that this privileged status does not rest solely on nationality provisions. For many years, immigrants originating from former colonies benefited from more lenient immigration rules. Until 2007 they were given fast-track benefits in access to a permanent residence permit. The new Portuguese Immigration Law (Law 23/2007) eliminated the Lusophone privilege in the access to a permanent residence permit, but still allows for an easier visa procedure for obtaining a residence permit for studies, student exchanges and professional pro bono internships in case of programs involving the Comunidade dos Países de Língua Portuguesa (CPLP) or the European Union (EU). The new 
Immigration Law also includes the requirement to speak basic Portuguese as a condition for granting a permanent residence permit and the long-term resident status. Furthermore, the extraordinary regularisation procedures of illegal immigrants that Portugal undertook in the 1990s were designed with a preferential bias for illegal immigrants originating from Portuguese speaking countries (DecreeLaw 212/92 and Law 17/96).

Most importantly, Lusophone foreigners benefit in Portugal from a quasi- citizenship status, enshrined in the Constitution. Unlike other foreigners, who do not have political rights and cannot exercise public functions which encompass any extent of sovereign power, Lusophone citizens can be part of political parties, vote in all elections and referenda, be candidate to the Parliament and in the municipal and regional elections, be a minister or deputy minister, be a judge or a public prosecutor, be a member of the police, be a civil servant and a director of the Public Administration. The Law on the municipal elections (Organic Law 1/2001) recognises, under reciprocity, the right to vote and to stand for elections, to citizens of Portuguese speaking countries with lawful residence in Portugal for more than two and four years. This requirement of a minimum of lawful residence for foreigners from Lusophone countries, even if more favourable in comparison with foreigners in general, who are required three and five years of lawful residence, is a form of negative, and arguably unconstitutional discrimination in comparison with the status of European Union citizens (Miranda, 1998: 155-156). The only positions inaccessible to Lusophone citizens are the office of President of the Republic, President of the Parliament, Prime-Minister, and Presidents of the Supreme Courts, as well as the service in the armed forces and in the diplomatic career. There is, however, one important caveat when discussing the privileged status of Lusophone citizens in Portugal, and that is that this privilege is based on the principle of reciprocity: Portuguese citizens must benefit from equal rights in other Lusophone countries as a condition for persons from those countries to enjoy equal rights in Portugal. Portugal currently only has concluded bilateral treaties on reciprocity with Brazil and Cape Verde (the largest migrant sending countries), which means that only immigrants from those countries can benefit from the constitutional privilege for persons from Lusophone countries residing in Portugal. It should also be mentioned that Brazilian citizens benefit from an even stronger status than their Cape Verdean counterparts, since they are entitled to a special equality status (estatuto de igualdade) under the "Friendship Treaty" (Tratado de Amizade, Cooperação e Consulta) signed by Portugal and Brazil in 2000. 
Brazilian citizens holding a special equality status are entitled to the same rights and subject to the same duties as Portuguese citizens, except the right to diplomatic protection in a third State, the right to access positions as President of the Republic, President of the Parliament, Prime-Minister, Presidents of the Supreme Courts, the right to serve in the Military and to access the diplomatic career (Decree-Law 154/2003, of 15 July).

\section{The Dutch experience}

The Netherlands, developing into an important naval power following Portugal and Spain, was a colonial power from the seventeenth to the twentieth century. The largest Dutch colony, by far, was the Dutch East Indies, nowadays known as Indonesia. After Indonesian independence in 1949, the Netherlands retained New Guinea, which would become independent in 1962 (and annexed to Indonesia in 1969). The second largest colony was Surinam, in South America, which would become independent from the Netherlands in 1975. Thirdly, the Netherlands Antilles is an island group in the Caribbean which still forms part of the Kingdom of the Netherlands to this day.

Dutch colonialism was driven strongly by political and economic elites, particularly within the frame of the Dutch East and West Indies Companies. This first of all gave the Dutch colonial expansion a strong 'corporate' character: driven by a mercantilist interest but clearly state-sponsored (Adams, 1996). Secondly, and particularly interesting in contrast with the Portuguese colonial experience, this also had strong impact on the way in which the Dutch colonized: "In the East, and particularly in the Indonesian archipelago, the Dutch were colonizers without a strong cultural impact, willing to tolerate if not necessarily appreciate the local elites' culture" (Oostindie and Paasman, 1998: 355).

With regard to the citizenship regime in colonial times, for most of the twentieth century Dutch citizenship policy was determined by the 1892 Nationality Act, of which the central feature was the principle of ius sanguinis a patre: a child obtained Dutch citizenship if its father was in possession of Dutch citizenship. With regard to residents of the overseas colonies, the 1892 Nationality Act granted full citizenship to the children of Dutch residents of the overseas colonies, while explicitly denying it to the "aboriginal or coloured people" living in the colonies (Vink, 2005: 146-147). 
The population of the Dutch East Indies was racially divided into two categories: "Europeans and assimilated", mostly Christians, and "natives and assimilated", mainly Arabs, Chinese, Mohammedans and pagans. In 1910 the indigenous population of the Dutch East Indies became "non-national Dutch subjects" (Nederlandseonderdanenniet-Nederlanders), a status that was extended to the indigenous populations of the Netherlands Antilles and Surinam in 1927. The introduction of this status, necessary to rule the indigenous population of the colonies, meant that they did not obtain full citizenship but only a restricted form of "subjecthood". Apart from the limited political rights, this status meant that persons with this subject status could not settle freely on Dutch territory in Europe and did not enjoy diplomatic protection as Dutch nationals (Vink, 2005: 36). The different legal categorization of the colonial rulers and their offspring, on the one hand, and the indigenous population, on the other, highlights the use of different standards by the colonial power. "As the absence of serious debates about issues such as colonialism or slavery attest, in the metropolis the colonies were seen as another world, where Dutch standards of culture, freedom, and civility did not apply" (Oostindie and Paasman, 1998: 355). This exclusionary conception of citizenship vis-à-vis the indigenous colonial population had already been explicitly justified by the Minister of Justice in a parliamentary debate in 1850: "Why call them Netherlanders? It would be a community in name without any community of law or common nationality. That is the main reason. Netherlanders, in line with this proposal, are the members of the Netherlands nation. It would be more just, I believe, to grant membership of the Netherlands nation to Germans or English, than to the indigenous population of Java or the Moluccans" (cited in Heijs, 1995: 36). This differential attitude remained dominant until the end of the colonial era.

In 1949, when Indonesia became independent, Dutch citizens were the European born settlers as well as the offspring of mixed unions (Indische Nederlanders), provided that these unions were legal. Faced with the need to incorporate the offspring of interracial unions in the racial classification on which the laws and rules of the colony depended, the Dutch found a legalistic answer: when the descendants of mixed relations were legal, they were Dutch; when the relation was not in any way legalized, then the offspring belonged to the native population (Van Amersfoort and van Niekerk, 2006: 325). In the so-called Round Table Conference in The Hague, in the Fall of 1949, representatives of the governments of the Netherlands and Indonesia, as well as the UN Commission for Indonesia in a mediating capacity, agreed that as part of the transfer of sovereignty an 'active system' of nationality choice 
would be adopted for adult Dutch nationals born in Indonesia or resident in that country for at least the last six months. Within a period of two years, ending at 27 December 1951, these persons could opt for Indonesian nationality. If they would not do so, they would remain Dutch nationals (Van der Veur, 1960).

The Dutch government encouraged the persons of mixed Dutch-Indonesian descent to opt for Indonesian nationality and provided financial support to persons who stayed in the former colony, but only around 13.000 of the total group of around 250.000 Indonesian Dutch actively opted to be Indonesian (Van Oers et al., 2010). The Dutch Government had no option but to repatriate its Eurasian citizens to the Netherlands and to promote their fast integration into Dutch society (Van Amersfoort and van Niekerk, 2006: 326). In the 1960's the Dutch Ministry of Justice instituted fast-track naturalization proceedings for the reacquisition of Dutch nationality by people who had opted for Indonesian citizenship in the period of 1949-51 and later regretted this (the so-called "repenters"), as well as for the acquisition of Dutch citizenship by the so-called "social Dutch", non-acknowledged Indonesian children with a Dutch father, who had never had Dutch citizenship. Since the early 1950s, both groups also benefited from more lenient immigration policies. As of 1960, it was mostly Indonesians who acquired Dutch citizenship through naturalization (Van Oers et al., 2010). These measures were part of a broader liberalising policy that started in the early 1950s.

In 1951, Dutch citizenship was extended to all indigenous populations in the overseas colonies, which at the time were the peoples from New Guinea, Surinam, the Netherlands Antilles and Aruba. For the population of New Guinea this status was lost when New Guinea became part of Indonesia on 14 September 1962. The Surinamese lost their Dutch citizenship as a consequence of Suriname's independence in 1975. The 1975 Allocation Agreement between the Netherlands and Surinam stipulated that the Dutch citizens living in Suriname on 25 November 1975 obtained Surinamese citizenship, except for the first generation Dutch citizens of European origin. The second generation Dutch citizens of European origin were given the right to opt for Dutch citizenship within a five-year transition period.

The Dutch citizens of Surinamese and Asian origin did not receive the right to opt for Dutch citizenship. The Agreement also stipulated that the acquisition of Surinamese citizenship entailed the loss of Dutch citizenship. The 1975 Agreement reflects the mounting concern regarding immigration restriction, but in fact large groups from Surinam were allowed to migrate to the Netherlands under condi- 
tions comparable to those of European Community workers during the five-year transition period until 1980 (Vink, 2005: 37). The only remaining Dutch overseas citizens are the people from the Netherlands Antilles and Aruba. As Dutch citizens they have the right to travel within the Kingdom and enjoy full political rights within their territory (Vink, 2005: 36). These rights include, since 2009, the right to vote and stand for election for the European Parliament. In the context of a revision of the autonomy status for these territories, however, there are on-going discussions about the extent to which these overseas Dutch citizens should benefit from the right of abode in the Netherlands.

Following the ratification of several international human rights treaties, naturalisation began to be perceived as an individual right and not as a purely discretionary concession by the State. It was decided that the legal position of applicants ought to be improved and that the naturalisation procedure had to be simplified. A reform to the 1892 Nationality Act, in 1976, established that certain categories of applicants for naturalisation could be awarded Dutch citizenship upon a simple decision by the Minister of Justice, instead of by Act of Parliament. This new procedure applied to applicants having a strong connection with the Netherlands, which the Dutch Government considered to include, among others, former Dutch citizens, former Dutch subjects and former non-Dutch citizens, mostly Surinamese citizens who had settled in the Netherlands after Surinam's independence and Indonesian "repenters" who had not yet acquired Dutch citizenship. Most naturalisations occurred in between 1957 and 1984, concerned immigrants from the former colony of Surinam (Van Oers et al., 2010).

In 1976, the Dutch Government accorded a quasi-citizenship status to the former inhabitants of the Moluccas, one of Indonesia's archipelagos, many of whom had served in the Dutch army against Indonesia and had been transported to the Netherlands with their families in 1951 and 1952. In the first years of their stay in the Netherlands, both the Dutch Government and the Moluccans expected the establishment, in the near future, of an independent South Moluccan Republic and viewed their presence as temporary, so no measures were taken to promote their integration into Dutch society. The Moluccans were temporarily housed in camps, mostly in rural areas and near small towns, which contributed greatly to their isolation from Dutch society (Van Amersfoort and Van Niekerk, 2006: 330). Because they never acquired Indonesian citizenship and did not want to become Dutch citizens, most of the Moluccans in the Netherlands were stateless. Following a series of violent actions on the part of Moluccans, in the early 1970s, the 
Dutch Government decided to improve their situation. It offered them almost equal rights to Dutch citizens, without making them Dutch citizens. The rights were incorporated in the 1976 Act on the position of Moluccans, which applied to Moluccans brought to the Netherlands by the Dutch Government in 1951 or 1952 and resident in the Netherlands on 9 September 1976, provided they did not already possess Dutch citizenship. The Act also applied to the children of these Moluccans, provided they were resident in the Netherlands on 9 September 1976, the date in which the Act entered into force. In 1976, the number of Moluccans who acquired the status rounded 30,000, but nowadays only a very small number of Moluccans still have it (probably less than 1000). For the most part, the second and third generations have acquired Dutch citizenship through naturalisation (Van Oers et al., 2010). The Moluccans have at last become "normal immigrants" (Van Amersfoort and Van Niekerk, 2006: 333).

Starting in the 1980's, citizenship became intertwined with immigration policies, since it was perceived as a fundamental tool for integration. After realising that most immigrants would stay permanently in the Netherlands, the Dutch Government decided to improve the immigrants' legal position by facilitating access to Dutch nationality. The new Dutch Nationality Act, which came into force on 1 January 1985, provided for the right of migrant children born on Dutch territory to opt for Dutch nationality and contained relatively easy naturalisation conditions. Those born on Dutch territory were granted the right to opt for Dutch citizenship between the ages of 18 and 25, under the condition that they had been residing on Dutch territory since birth. Contrary to the naturalisation procedure, the option procedure was a unilateral declaration by the applicant, without further conditions. There was no obligation to renounce the former citizenship and no public order or integration requirements to be met. This right of option ended up not having a significant impact, since most immigrant children acquire Dutch citizenship upon naturalisation of their parents. Its regime was considerably changed by the 2003 reform. In order to be eligible for naturalisation, the applicant must: a) be at least eighteen years of age; b) have been granted a permanent residence permit in the Netherlands; c) have resided in the Netherlands for at least five consecutive years prior to the application; d) not constitute a danger to public order, public morals, public health or the security of the Kingdom; e) have made an effort to renounce his or her foreign citizenship, unless renunciation cannot be demanded (either because the laws of the country of origin do not allow it or because renunciation would cause disproportionate damage to the applicant) 
(De Groot, 2003; Van Oers et al., 2010). Due to the fact that naturalisation became more difficult since 2003, the option procedure became more important in the access to citizenship.

Keeping with the double ius soli rule, in force since 1953, the Act also granted Dutch citizenship by birth to third generation immigrants, who were expected to integrate automatically into Dutch society hence justifying the acquisition of Dutch citizenship at birth. Integration into Dutch society was simultaneously a goal and a pre-requisite for naturalisation, the main prerequisite as a matter of fact. The 1985 Act defined integration into Dutch society as having a reasonable knowledge of Dutch language and having been accepted into Dutch society, while the renunciation requirement is used as an extra criterion for assessing integration. In practice, only the language test was used to judge whether an applicant fulfilled the integration requirement. If this requirement was met, it was assumed that the applicant maintained contact with Dutch citizens. The language requirement was considered to be met if the applicant was able to apply for naturalisation on his or her own and if he or she could have a conversation about common and daily affairs. The Manual on the application of the Dutch Nationality Act mentioned illiterates, persons with limited education, and the elderly as categories of persons who were to be treated flexibly when it came to knowledge of the Dutch language. Only in the case of bigamy would sufficient language skills not suffice for a positive judgement on integration (Van Oers et al., 2010).

The 1992 reform made naturalisation even easier by waiving the requirement of renunciation by the applicant of his or her citizenship of origin (Vink, 2005). The renunciation requirement was reintroduced in 1997, after a considerable rise in the number of naturalisations, which prompted the idea that immigrants were being treated too liberally, with many rights and no obligations. The renunciation of the applicant's nationality of origin is still required today, even if many exceptions to the rule have been added through the years. The 1998 Act on the Civic Integration of Newcomers, which introduced newcomer programmes, required individual immigrants to take obligatory language and societal knowledge courses. The term "active citizenship" was introduced to emphasise the responsibility of each individual for his place in society (Van Oers et al., 2010).

Following the events of 2001 and 2002 (the politically motivated murders of Pim Fortuyn and Theo van Gogh), the atmosphere became even tenser and the old model of integration of immigrants into Dutch society was declared a failure. 
Multicultural policies gave place to a more assimilationist approach, with immediate repercussions for Dutch nationality law. The 2003 reform introduced stricter integration requirements for naturalisation, including lawful and uninterrupted residence in the Netherlands in the five years prior the application and a "naturalisation test" in which the applicants have to prove sufficient knowledge of Dutch society and to be able to speak, understand, read and write Dutch. This naturalisation test was replaced, in 2007, by an "integration exam", to be administered to both applicants for naturalisation and applicants for permanent residence in the Netherlands. Some categories of immigrants are exempted from the integration exam, as were exempted from the naturalisation test. Among them are the Moluccans who, on the basis of the 1976 Act are treated as Dutch citizens. The 2003 reform also instituted a ceremony for the celebration of the acquisition of Dutch citizenship. Instead of being perceived as a tool for integration, Dutch citizenship is increasingly more regarded as a reward for good integration, as the "crown on the completed integration process".

\section{Comparison and discussion}

Portugal was the last of the European empires to surrender its colonies and it was the one who suffered the lost most. Portugal's postcolonial reconstruction revolves around the maintenance of special ties with its former colonies, even if the perception of the emotional and cultural ties between Portugal and its former colonies can be largely exaggerated (Almeida, 2001: 583). The Lusotropicalist perception of Portugal's gift for intercultural dialogue is a very powerful element of the Portuguese psyche, so much so that some speak of a psychoanalytical 'complex' that still haunts Portugal today (Almeida, 2008).

The contrast with the Netherlands, where no programmes exist that involve the entire former Dutch 'colonial orbit', could not be starker (Oostindie, 2008: viii). This is first of all a natural consequence of the fundamentally different character of Dutch colonialism, according to Oostindie (2008: 8): "It has often been observed that the Dutch colonial legacy pales in comparison to legacies left by other European colonies. Language is the most striking case in point. Dutch was only spoken by tiny minorities in Asia and left only a few traces, even in Indonesia, although a great number of Dutch words made their way as loanwords into Indonesian." If there is talk about colonialism in the contemporary, this is rather about a 'colonial neglect' than about a 'colonial complex' (Oostindie, 2009). 
These different postcolonial attitudes in the former metropolis also reflect on the relation between former colonisers and former colonies. Relations between the Netherlands and Indonesia, in particular, have been fraught with diplomatic rows and sensitivities. A good example is the longstanding reluctance to recognize 1945 as the start of Indonesian independence following a unilateral declaration of independence, rather than 1949 which is the year of the official transfer of sovereignty. It took until 2005 for the Dutch government to recognize "that Indonesian independence, politically and morally, commenced in fact in 1945." The traditional emphasis on human rights in Dutch foreign policy, on the one hand, and its desire to maintain friendly relations with Indonesia also frequently clashed. Political criticism from the Netherlands on the democratic and human rights situation in post-independence Indonesia, for example regarding the situation in EastTimor, also frequently contributed to sour diplomatic relations between the two countries in the postcolonial context and obstructed development cooperation (Baehr, 1997).

Until the 1990s that was not much different between Portugal and its former colonies. The relations between Portugal and its former colonies in Africa (Angola and Mozambique, in particular) were, up until the mid 1990s, extremely tense and fraught with mutual mistrust. The Portuguese-Brazilian relations, friendly as they officially are, have always been loaded with mutual reserve and rivalry. The creation of the Portuguese Speaking Countries Community (CPLP), in 1996, can be said to have marked a new era of good relations between the Lusophone countries, but the fact is that the Lusophone ties are often superseded by other, more strategic, ones. They did not prevent Mozambique from joining the British Commonwealth, in 1995, and Guinea-Bissau from gravitating towards francophonie and entering the African franc zone in 1997 (MacQueen 2003: 190-198). Portugal's preferential ties are with the European Union, Brazil's with the Mercosul, CapeVerde, Angola, Mozambique, S. Tomé and Príncipe and Guinea's with the African Union, and Timor-Leste's with the Association of South-East Asian Nations (ASEAN). Moreover, the CPLP is not free from the suspicion of a neo-colonialist agenda on the part of Portugal (Macqueen, 2003: 199).

These differences in terms of strength of bilateral and even multilateral postcolonial relations are also reflected in contemporary citizenship and migrations regimes in Portugal and the Netherlands, as discussed extensively in this paper. On behalf of its special ties with the Lusophone world, Portugal has favoured Lusophone foreigners in their access to Portuguese nationality and territory. These privileges, 
for example in the citizenship law, have been largely abolished due to European constraints, but the fact remains that the "Lusophone citizens" are a special category of foreigners, entitled to citizenship rights that are denied to all other foreigners, including EU citizens.

The Netherlands do not grant such privileged status to its post-colonial immigrants. Even if it adopted special transitory measures in order to foster the integration of immigrants originating from Indonesia and Suriname, in the 1950s and 1970s, and granted the Moluccans a quasi-citizenship status, the Netherlands soon began treating the people coming from its former colonies as mere foreigners, with no special rights of access to the Dutch territory or citizenship and enjoying only the political rights that may be awarded to all foreigners, such as the right to vote in local elections. Although the integration of post-colonial immigrants into Dutch society might have been made easier by their cultural capital, in terms of familiarity with the Dutch language and culture, such privileges are, in contrast with the Portuguese case, not translated in legal privileges. The comparison between the two cases highlights the different approaches to citizenship in a postcolonial context.

\section{Bibliographic References}

ADAMS, Julia, Principals and Agents, Colonialists and Company Men: The Decay of Colonial Control in the Dutch East Indies, in "American Sociological Review", Vol. 61, No. 1, 1996.

ALEXANDRINO, José de Melo, A nova lei de entrada, permanência, saída e afastamento de estrangeiros, Lisboa, 2008.

ALMEIDA, Miguel Vale de, Epilogue of Empire: East Timor and the Portuguese Postcolonial Catharsis, in "Identities", Vol. 8, No. 4, 2001.

ALMEIDA, Miguel Vale de, Portugal's Colonial Complex: From Colonial Lusotropicalism to Postcolonial Lusophony, Queen's Postcolonial Research Forum, Queen's University, Belfast, 2008.

BAEHR, Peter R., Problems of Aid Conditionality: The Netherlands and Indonesia, in "Third World Quarterly", Vol. 18, No. 2, 1997.

CANAS, Vitalino, Nacionalidade Portuguesa depois de 2006, in vv.aa., Estudos em Homenagem ao Professor Doutor Marcelo Caetano no centenário do seu nascimento, Vol. II, Lisbon, Faculdade de Direito da Universidade de Lisboa, 2006.

CARVALHAIS, Isabel, Citizenship Policymaking in Mediterranean EU States: Portugal, Comparative Report, RSCAS/EUDO-CIT-Comp. 2010/3, 2010.

CASTELO, Cláudia, O modo português de estar no mundo. O luso-tropicalismo e a ideologia colonial portuguesa (1933-1961), Porto, Edições Afrontamento, 1999. 
DARIAN-SMITH, Eve, Postcolonialism: A Brief Introduction, in "Social \& Legal Studies", Vol. 5, No. 3, 1996.

DE GROOT, Gerard-René, Handboek Nieuw Nationaliteitsrecht, Deventer, Kluwer, 2003.

HEIJS, Eric, Van Vreemdeling tot Nederlander, Amsterdam, Het Spinhuis, 1995.

HORTA, Ana Paula Beja, and WHITE, Paul, Post-colonial Migration and Citizenship Regimes: A Comparison of Portugal and the United Kingdom, in "Migrações", 4, 2009.

KAPUR, Ratna, The Citizen and the Migrant: Postcolonial Anxieties, Law, and the Politics of Exclusion/Inclusion, in "Theoretical Inquiries in Law", Vol. 8, No. 2, 2007.

MACHADO, Fernando Luís, Luso-Africanos em Portugal: nas Margens da Etnicidade, in "Sociologia. Problemas e Práticas", 16, 1994.

MACQUEEN, Norrie, Re-defining the 'African Vocation': Portugal's Post-colonial Identity Crisis, in "Journal of Contemporary European Studies", Vol. 11, No. 2, 2003.

MARQUES, José Augusto Garcia, O Direito, a Lusofonia e Macau, in "ScientiaIuridia", LVI, $311,2007$.

MCCLINTOCK, Anne, The Angel of Progress: Pitfalls of the Term "Post-Colonialism", in "Social Text", 31/32, 1992.

MEZZADRA, Sandro, and RAHOLA, Federico, The Postcolonial Condition: A Few Notes on the Quality of Historical Time in the Global Present, in "Postcolonial Text", Vol. 2, No. 1, 2006.

MIRANDA, Jorge, Manual de Direito Constitucional. III. Estrutura Constitucional do Estado, Coimbra, Coimbra Editora, 1998.

OOSTINDIE, Gert, Postkoloniaal Nederland: Vijfenzestigjaarvergeten, herdenken, verdringen, Amsterdam, Bert Bakker, 2009.

OOSTINDIE, Gert, ed., Dutch colonialism, migration and cultural heritage, Leiden, KITLV Press, 2008.

OOSTINDIE, Gert, and PAASMAN, Bert, Dutch Attitudes Towards Colonial Empires, Indigenous Cultures, and Slaves, in "Eighteenth-Century Studies", Vol. 31, No. 3, 1998.

PIÇARRA, Nuno and GIL, Ana Rita, Country Report: Portugal, Country Report, RSCAS/ EUDO-CIT-CR 2010/28, 2010.

RAMOS, Rui Manuel Moura, Nacionalidade e descolonização, in "Revista de Direito e Economia", 1, 1976;

-, La double nationalitéet les liens spéciaux avec d'autres pays. Les développementset les perspectives au Portugal, in "Revista de Direito e Economia", 16, 1990;

-, Do Direito Português da Nacionalidade, Coimbra, Coimbra Editora, 1992;

-, Continuidade e mudança no Direito da nacionalidade em Portugal, in vv. aa., PortugalBrasil Ano 2000, Coimbra, Coimbra Editora, 1999.

SANTOS, Boaventura de Sousa, Between Prospero and Caliban: Colonialism, Postcolonialism, and Inter-identity, in "Luso-Brazilian Review", Vol. XXXIX, No. 2, 2002. 
VAN AMERSFOORT, Hans, and VAN NIEKERK, Mies, Immigration as a Colonial Inheritance: Post-Colonial Immigrants in the Netherlands, 1945-2002, in "Journal of Ethnic and Migration Studies", Vol. 32, No. 3, 2006.

VAN OERS, Ricky, DE HART, Betty, and GROENENDIJK, Kees, Country Report: The Netherlands, 2010, EUDO Citizenship Observatory, http://eudo-citizenship.eu

VAN DER VEUR, Paul W., Eurasian Dilemmas in Indonesia, in "The Journal of Asian Studies," Vol. 20, No. 1, 1960.

VINK, Maarten, Limits of European Citizenship. European Integration and Domestic Immigration Policies, New York, Palgrave Macmillan, 2005. 